\title{
The Corporate Response to Government Attacks on Tax Shelters
}

\author{
Noel P. Brock ${ }^{1}$, Edward J. Schnee ${ }^{2} \&$ Shane R. Stinson ${ }^{2}$ \\ ${ }^{1}$ Eastern Michigan University, Ypsilanti, Michigan, USA \\ ${ }^{2}$ University of Alabama, Tuscaloosa, AL, USA \\ Correspondence: Shane R. Stinson, Culverhouse School of Accountancy, University of Alabama, Tuscaloosa, AL \\ 35487, USA.
}

Received: August 30, 2016

Accepted: September 26, 2016

Online Published: January 9, 2017

doi:10.5430/ijfr.v8n1p126

URL: http://dx.doi.org/10.5430/ijfr.v8n1p126

\begin{abstract}
We examine the effectiveness of four federal government actions, all of which were designed to curb the proliferation of corporate tax shelters dating back to the 1990s, at eliciting measurable changes in characteristics commonly associated with tax shelter firms. Our results suggest that the government's initial attacks on corporate tax shelters in the early 2000s elicited significant declines in book-tax differences, discretionary accruals, and the use of Big $\mathrm{N}$ audit firms, which contributed to gradual reductions in the estimated likelihood of tax sheltering for both multinational and purely domestic firms. Conversely, later attempts to discourage corporate tax shelters proved ineffective, likely due in part to the effectiveness of previous government attacks and a faltering economy. This study addresses calls from prior literature for a better understanding of factors determining corporate tax avoidance and offers new evidence of multi-faceted taxpayer reactions to corporate tax reform.
\end{abstract}

Keywords: Circular 230, corporate tax avoidance, reportable transactions, tax reform, tax shelters

\section{Introduction}

Public accounting firms became immersed in the creation and mass marketing of corporate tax shelters, specialty transactions designed to generate tax savings with little other connection to a taxpayer's ordinary operations, in the 1990s (Novak and Saunders 1998; Treasury 1999). The accounting firms behind these elaborate tax planning strategies often provided substantial services to clients under terms of confidentiality and with fee arrangements contingent upon a successful defense from any challenge by the Internal Revenue Service (IRS). Since 2000 and continuing through today, Congress, the U.S. Treasury, and the IRS have responded to this cultural shift by enacting many tax laws, regulations, and rulings attempting to curb the proliferation of corporate tax shelters and deter this form of corporate tax avoidance. However, to date there is little evidence indicating whether these attempts have or have not been effective. We seek to determine which, if any, recent regulatory and/or legislative actions (hereafter collectively referred to as "government actions") have elicited measurable changes in corporate tax sheltering as they were intended. Specifically, we investigate whether various attempts by Congress, the U.S. Treasury, and the IRS to curb the proliferation of tax shelters and/or close loopholes in the Internal Revenue Code (IRC) have had a discernable effect on firms' estimated likelihood of tax sheltering (Wilson 2009; Lisowsky 2010), which captures a wide assortment of factors associated with sheltering activity that is generally unobservable due to privacy restrictions on tax return data.

Empirical research has focused on stock price (e.g., Auerbach and Hassett 2007; Dhaliwal et al. 2007) and both corporate and individual reactions (e.g., Givoly et al. 1992; Feldstein 1995) to major changes in tax rate structures. However, relatively less is known about the effects of government actions that target specific weaknesses in the IRC or that generally attempt to curb the proliferation of tax shelters. While broad overhauls of tax rate structures are relatively infrequent, Congress issues new guidance and amendments to existing IRC sections every year, often with the stated objective of limiting opportunities for corporate tax sheltering. (Note 1) The U.S. Treasury and the IRS share similar goals, often targeting corporate tax shelters with new administrative guidance. These government actions receive a great deal of attention through political debate, lobbying, and popular media, and are often accompanied by estimates of expected revenue collections. Given such estimates and the frequency with which they are made, it is important to examine the impact of selected government actions on relevant measures of corporate tax avoidance (in this case, the estimated likelihood of tax sheltering) to provide more informed policy recommendations in the future. 
Beginning with 2000, we evaluate four government actions, not occurring in conjunction with major changes to corporate or individual tax rates, that attempted to deter corporate tax avoidance by closing loopholes in the IRC and/or increasing restrictions and monitoring requirements on tax shelters. Of the four government actions, three were designed to target the behavior of corporate taxpayers directly. For example, the 2000 and 2007 reportable transaction regulations required corporate taxpayers to report their participation in tax shelters and/or other "transactions of interest" motivated by potential tax savings. In addition, section 358(h) was enacted in late 2000 to eliminate the acceleration or duplication of deductions stemming from transfers of property to a corporation in exchange for stock and the assumption of contingent liabilities. (Note 2) Though these government actions vary considerably in their implementation, their shared focus on taxpayer behaviors seemingly makes them vulnerable to the substitution of known and scrutinized tax avoidance strategies for those that have yet to be confronted by taxing authorities. Furthermore, this reactive and iterative process of legislative discovery is perpetuated in part by tax preparers, who are employed by taxpayers with explicit objectives to devise new and creative ways of minimizing their respective tax burdens.

Our fourth selected government action differs from the previous three in that it was designed to impose greater accountability and harsher penalties on tax preparers. Specifically, the Treasury Department and the IRS amended Circular 230 in late 2004 and 2005 to create the concept of a "covered opinion" generated by tax practitioners to aid clients in devising tax avoidance strategies. These amendments imposed heightened requirements on advisers issuing covered opinions and included new restrictions on marketed opinions, conditions of confidentiality, and contractual protections, all of which fueled the mass marketing of corporate tax shelters by large public accounting firms and contributed to a cultural shift among tax practitioners in the 1990s (Novak and Saunders 1998). Such an approach by government officials is seemingly an attempt to cut off present and future acts of corporate tax sheltering at their primary source. However, we note that the use of foreign operations, an increasingly vital component of sustained performance in a globally competitive marketplace, likely insulates taxpayers from the full desired effects of government actions to deter corporate tax shelters, regardless of their focus on taxpayers or preparers. Thus, it is important to evaluate the ability of such varied government actions to produce desired changes in tax sheltering behavior in order to improve our understanding of corporate tax reform and better inform future policy.

Consistent with Wilson (2009) and Lisowsky (2010), we estimate a firm's likelihood of engaging in a tax shelter over multiple event periods preceding and following each of our selected government actions. We first examine aggregate changes in these likelihood estimates and their components to assess the nature of the corporate response to each legislative change. Next, we perform similar analyses on separate subsamples of multinational and purely domestic firms to investigate potential differences in this response based on a firm's opportunities to avoid undesirable U.S. legislation by way of foreign jurisdictions.

Our results suggest that the first two of our selected government actions - the 2000 Regulations and section 358(h) elicited declines in several characteristics associated with the use of corporate tax shelters. Specifically, our sample firms exhibited significant declines in book-tax differences, discretionary accruals, litigation payments, and performance while also migrating away from the Big $\mathrm{N}$ audit firms who championed a number of tax shelters in the 1990s. However, for the 2000 Regulations - which were implemented with little advance notice in the first quarter of 2000 - we find that the overall estimated likelihood of tax sheltering briefly increased before exhibiting modest declines in the period following the enactment of section 358(h) in the fourth quarter of 2000. These findings suggest that aggregate declines in tax sheltering behaviors were relatively slow to unfold following the government's initial attempts to combat them. Conversely, the aggregate decline in the estimated likelihood of tax sheltering under Circular 230, a preparer-focused piece of legislation amended in 2005, was immediate and driven predominantly by reductions in discretionary accruals, perhaps suggesting an increase in professional skepticism and/or accounting quality under increasing regulatory scrutiny. Separate analysis for multinational and purely domestic firms indicates that all three of these government actions elicited qualitatively similar responses from firms with and without foreign outlets for tax avoidance.

The last of our selected government actions - the 2007 Regulations - proved relatively ineffective in our analyses. These regulations were enacted shortly before the economic downturn that led to the Great Recession, and significant increases in discretionary accruals and NOL carryforwards in conjunction with declining performance in the period following the change in legislation suggest that temporary increases in the estimated likelihood of sheltering were likely the result of firms' efforts to combat heightened economic pressures. Additional analysis suggests that multinational firms were largely responsible for aggregate increases in the estimated likelihood of tax sheltering following the 2007 Regulations, while purely domestic firms showed little reaction. 
Our contributions to the tax literature are at least twofold. First, pursuant to the calls by Shackelford and Shevlin (2001) and Hanlon and Heitzman (2010) for a better understanding of factors determining corporate tax avoidance, we offer new evidence on the government's efforts to discourage a highly aggressive form of corporate tax avoidance that managers might otherwise pursue in order to please investors and maximize firm value (Slemrod 2004; Crocker and Slemrod 2005; Desai et al. 2007; Hoopes et al. 2012). Second, we offer evidence of multi-faceted taxpayer reactions to corporate tax reform, which suggests that various pieces of legislation can produce similarly encouraging results for vastly different reasons (e.g., section 358(h) vs. Circular 230), or perhaps yield disappointing results due to issues largely beyond regulatory control (e.g., the 2007 Regulations).

The remainder of our article is organized as follows. Section 2 presents a review of relevant literature and recent government attacks on corporate tax shelters leading to the development of our hypotheses. Section 3 describes our empirical methods and results. Finally, Section 4 offers concluding remarks.

\section{Review of the Literature and Development of Hypotheses}

\subsection{Recent Government Actions against Corporate Tax Shelters}

Historically, business tax planning usually occurred in connection with real economic transactions. Later, investment banks began devising tax planning strategies, now commonly referred to as "corporate tax shelters," that were primarily motivated by tax savings and otherwise lacked strategic and/or operational evidence of economic substance (e.g., Harvey 2014; Donohoe et al. 2014). The investment banks would typically sell a strategy to a few select clients and then shut it down (i.e., not sell it to more clients). Beginning in the 1990s, however, the largest accounting firms in the U.S. began pushing corporate tax shelters. These tax shelters were peddled to thousands of companies. They were usually offered on conditions of confidentiality and were subject to contractual protections that promised a refund of part or all of a client's fees if part or all of the intended tax consequences were not finally sustained after an IRS challenge, if any (Novak and Saunders 1998).

Since 2000, Congress has enacted numerous revisions and extensions of the IRC and the U.S. Treasury and IRS have issued numerous items of administrative guidance in response to this surge in aggressive tax planning. We evaluate four of these government actions that attempted to deter corporate tax avoidance by closing loopholes in the IRC and/or increasing restrictions and monitoring requirements on tax shelters. We offer a brief chronological review of our selected government actions in the following paragraphs.

\subsubsection{Reportable Transaction Regulations - Effective Q1 2000}

The IRS and U.S. Treasury began promulgating Regulations designed to stop the proliferation of corporate tax shelters with the issuance of T.D 8875, T.D. 8876, and T.D. 8877 in February 2000 (2000 Regulations). These so-called "reportable transaction regulations" applied to both tax preparers and taxpayers, but the primary impact was on taxpayers. Among other things, the 2000 Regulations required certain taxpayers (initially only corporate taxpayers but eventually extended to individuals, trusts, partnerships and S corporations) to report to the IRS any "corporate tax shelter," which was defined as either a listed transaction (one of a select few transactions the IRS had issued a notice proclaiming them to be listed transactions) or a transaction containing certain characteristics common to corporate tax shelters of the day (confidentiality provisions, contractual protection, contingent fees, book-tax differences, indifferent party involvement, brief asset holding period, and different US and foreign tax treatment). These disclosures, which include the type, nature, and estimated tax benefits of the transaction as well as identifying information for its promoters and advisers, were first required by T.D. 8877 in statements attached to the taxpayer's return and were later captured on Form 8886, which accounting researchers have since used to examine the behavior of tax shelter firms (e.g., Lisowsky 2010). The 2000 Regulations also required tax shelter promoters, generally persons who organize or sell an interest in a potentially abusive tax shelter, including accounting firms engaged in the proliferation of tax shelters, to register each tax shelter with the IRS using Form 8264 and keep a list of its participants available for inspection upon request by the Secretary of the Treasury.

\subsubsection{Section 358(h) - Effective Q4 2000}

Other government actions were narrowly targeted to combat a specific transaction that the government had discovered. Such was section 358(h).

Congress became aware of a type of transaction in which taxpayers obtained control of a corporation and sought to accelerate (and potentially duplicate) deductions involving the transfer of contingent liabilities, which had not yet satisfied the "all events test" under section 461 at the time of the exchange that would give rise to a tax deduction. For example, a transferor corporation might transfer assets with a fair market value basis (i.e., a tax basis equal to fair market value) in exchange for preferred stock of the transferee corporation, plus the transferee corporation's 
assumption of a contingent liability that is deductible in the future. The transferor corporation would claim a basis in the stock received equal to the original fair market basis of the assets transferred, but would not adjust its basis downward for the assumption of the contingent liability because it had no value for tax purposes at the time of the exchange. Conversely, the market value of the stock received by the transferor would equal the original fair market basis of the assets transferred less the amount of the contingent liability assumed, thereby leaving the transferor with a potential loss (i.e., tax basis in excess of market value). The transferor corporation would then attempt to accelerate the deduction attributable to the liability by selling or exchanging the stock. Furthermore, the transferee might also take the position that it was entitled to deduct its eventual payments on the assumed contingent liability, effectively duplicating the deductions attributable to the liability.

Enacted as part of the Community Renewal Tax Relief Act in December 2000 (P.L. No. 106-554) and effective for liability assumptions on or after October 18, 1999, section 358(h) attempts to eliminate acceleration or duplication of deductions by requiring that, if the basis of stock acquired (before applying section 358(h)) exceeds its fair market value, then the basis of the stock received is reduced (but not below its fair market value) by the amount of any liability that (1) is assumed in exchange for such stock, and (2) did not otherwise reduce the transferor's basis of the stock by reason of the assumption. (Note 3 )

\subsubsection{Circular 230 - Amended Q2 2005}

Circular 230 generally governs attorneys, certified public accountants, enrolled agents, and other persons representing taxpayers before the IRS. (Note 4) It differs from the previous items of guidance discussed in that it applies solely to tax return preparers - not to taxpayers. Further, Circular 230 applies to individual persons and has no application to a firm. (Note 5) Thus, tax advisers working in firms who represent taxpayers before the IRS (for example, by signing a tax return) may not assert as a defense to a violation of Circular 230 that the firm (or any member of the firm) signed off on the item. Each person representing taxpayers before the IRS must know and understand Circular 230 and independently assess whether s/he is in compliance with Circular 230 at all times.

On December 30, 2003, the Treasury Department and the IRS published in the Federal Register (68 FR 75186) proposed amendments to the regulations (REG-122379-02) to set forth best practices for tax advisors providing advice to taxpayers relating to federal tax issues or submissions to the IRS and to modify the standards for certain tax shelter opinions. After thorough consideration of public comments, the U.S. Treasury and IRS revised Circular 230 in December 2004 (69 Fed. Reg. 75,839) and May 2005 (T.D. 9201) in an effort to curb the proliferation of tax shelters. (Note 6) In particular, Circular 230 was revised to create the concept of a "covered opinion" and imposed heightened requirements on advisers issuing covered opinions. (Note 7) New rules on marketed opinions, conditions of confidentiality, and contractual protection rules were also implemented in direct response to marketplace conditions under which the largest accounting firms were operating at the time (e.g., Novak and Saunders 1998). (Note 8) Anecdotal evidence from practitioners suggests this prompted some tax preparers to increase disclosures on Forms 8275 and $8275-\mathrm{R}$ on client tax returns.

\subsubsection{Reportable Transaction Regulations - Effective Q3 2007}

As a result of changes to sections 6111 and 6112 by the American Jobs Act of 2004 (Pub. L. No. 108-357, 118 Stat. 1418) enacted on October 22, 2004, the U.S. Treasury and IRS further interpreted sections 6011 and 6112 with the issuance of T.D. 9350 in September 2007 (2007 Regulations). (Note 9) This government action identified "transactions of interest" as a new category of reportable transactions, allowing greater flexibility and discretion in the identification of tax shelters. T.D. 9350 defines a transaction of interest as a "transaction that the IRS and Treasury Department believe has a potential for tax avoidance or evasion, but for which the IRS and Treasury Department lack enough information to determine whether the transaction should be identified specifically as a tax avoidance transaction." Thus, the 2007 Regulations expanded the reach of those established in 2000, again focusing on taxpayer behaviors to curb various tax shelter activities. This expansion led to a revision of Form 8886 for taxpayers to disclose their participation in tax shelters. In addition, the disclosures required on Form 8264 for the promoters and material advisors of tax shelters following the 2000 Regulations were replaced with Form 8918, though material advisors were still required to maintain lists of tax shelter participants and make them available for IRS inspection.

\subsection{Impact of Recent Government Actions on Corporate Tax Shelters}

While the government actions described above differ widely in their implementation and penalty structures, all of them were designed with explicit goals of discouraging the proliferation and mass marketing of tax shelters. Thus, if these government actions were effective in achieving their goals, we should observe declines in the use of corporate 
tax shelters in the periods immediately following each change in legislation as compared to the periods immediately preceding each change. Unfortunately, this phenomenon is not readily observable to the authors or the general public. Despite the government's efforts to change corporate behaviors and increase the quantity and quality of information reported to the IRS with each act, privacy restrictions on tax return data still prevent the positive identification of tax shelters that can be linked to a firm's financial statements and other publicly available data sources in an archival research setting.

To combat this issue, prior research (e.g., Wilson 2009; Lisowsky 2010) has investigated known tax shelter firms and identified several common characteristics that can be gleaned from publicly available data sources and used to estimate the likelihood that a given firm may be engaged in a tax shelter. Such characteristics include a firm's book-tax differences, discretionary accruals, leverage, size, ROA, research and development expense, effective tax rates, mezzanine financing, audit firm, litigation settlements, and net operating losses. We assert that the effect of each of our selected government actions on corporate tax sheltering behavior should manifest in changes in this profile of firm-level characteristics immediately after each piece of legislation was implemented. Stated formally, we posit the following:

H1: The likelihood that a firm may be engaged in a tax shelter declines in response to government action against corporate tax shelters.

Conversely, a plateau or increase in the average estimated likelihood of a firm's involvement in tax shelters following one of our selected government actions could suggest (1) that firms substituted behaviors specifically targeted by the government with other tax avoidance schemes, (2) that the government overestimated the prevalence and magnitude of the behavior it sought to discourage, and/or (3) that the government overestimated the ability of a given policy change to restrict the aggressive behavior it was intended to deter.

\subsection{Impact of Foreign Operations on Firm Responses to Government Actions}

Assuming management incentives to avoid taxes and maximize profits are unaffected by new instances of corporate tax reform, it follows that changes in prevailing tax policy perpetuate the process by which firms seek alternative methods of tax avoidance. Further, by spreading income-producing activities and resources over multiple jurisdictions, presumably to those whose tax rate structures and enforcement policies are less stringent than those of the U.S. and whose foreign income is generally not taxed in the U.S. unless and until it is repatriated, firms with overseas operations are arguably more insulated from the government actions described herein. Such insulation might encourage multinational firms to resist particularly onerous government actions against corporate tax shelters, perhaps by shifting more of their operations and/or more of their aggressive tax planning strategies to foreign jurisdictions. Conversely, multinational firms are generally larger than those who operate exclusively in the U.S., and thus may face greater scrutiny from investors, the media, and regulators. This enhanced scrutiny might compel multinational firms to respond to legislative change with more enthusiasm than purely domestic firms who spend relatively less time in the public eye. Given these conflicting perspectives, we pose the following research question:

RQ1: Does the response to government action against corporate tax shelters differ for multinational and purely domestic firms?

\section{Empirical Methods and Results}

\subsection{Sample}

Our goal is to measure behavior associated with the use of tax shelters in the periods immediately preceding and following our selected government actions, and we base our sample selection process largely on Lisowsky (2010). As indicated in Panel A of Table 1, we begin by collecting data necessary to estimate components of the Lisowsky (2010) and Wilson (2009) likelihoods of tax sheltering from Compustat. This yields an initial sample of 90,930 firm-quarter observations. We then eliminate all financial firms (SIC 6000-6999), firms incorporated outside the U.S., and any other firms with missing data. Next, we merge estimated discretionary accruals (Dechow et al. 1995; Kothari et al. 2005; Amiram et al. 2013) with our dataset and eliminate industries with fewer than 15 unique firms for each of our selected government actions, producing a total of 34,689 firm-quarter observations. Finally, we merge this collection of firm-quarter observations to obtain unique firm-level averages over event windows ranging from two to eight quarters preceding and following each government action, excluding the effective quarter. (Note 10) This process yields a combined sample of 1,866 observations, with one observation for each unique firm under each government action. 
Table 1. Sample selection

\section{Panel A: Data Collection Steps}

Data Selection Step

Obs. Lost

Total $\mathbf{N}$

Collect initial Compustat data to estimate tax shelter likelihood and component variables, 1995-2010

Delete financial firms (SIC 6000-6999), firms incorporated outside

the U.S., and observations lacking required data

$(19,634)$

71,296

Merge estimated discretionary accruals

$(35,388)$

35,908

Delete industries with fewer than 15 unique firms per government

action

34,689

Merge observations for unique firms with nonmissing values, estimate firm-level averages over 2-, 4-, 6-, and 8-quarter pre-post periods ( 1 observation per firm per government action)

Panel B: Breakdown of Final Sample by Government Action, Foreign Operations, and Industry

\begin{tabular}{lcrrrrr} 
Industry & $\begin{array}{c}\text { Foreign } \\
\text { Operations }\end{array}$ & $\begin{array}{c}\mathbf{2 0 0 0} \\
\text { Regs. }\end{array}$ & $\begin{array}{c}\text { Sec. } \\
\mathbf{3 5 8}(\mathbf{h})\end{array}$ & $\begin{array}{c}\text { Circular } \\
\mathbf{2 3 0}\end{array}$ & $\begin{array}{r}\mathbf{2 0 0 7} \\
\text { Regs. }\end{array}$ & Total N \\
Construction & No & 15 & 14 & 25 & 24 & 78 \\
(SIC 2000-2999) & Yes & 32 & 28 & 44 & 48 & 152 \\
\hline Manufacturing & No & 48 & 43 & 51 & 49 & 191 \\
(SIC 3000-3999) & Yes & 168 & 167 & 189 & 168 & 692 \\
\hline Wholesale, Retail & No & 47 & 45 & 49 & 45 & 186 \\
(SIC 5000-5999) & Yes & 24 & 21 & 31 & 37 & 113 \\
\hline Hotels, Services & No & 28 & 21 & 22 & 23 & 94 \\
(SIC 7000-7999) & Yes & 71 & 68 & 77 & 68 & 284 \\
\hline Services & No & 7 & 6 & 12 & 14 & 39 \\
(SIC 8000-8999) & Yes & 9 & 8 & 9 & 11 & 37 \\
\hline Total & No & 145 & 129 & 159 & 155 & 588 \\
& Yes & 304 & 292 & 350 & 332 & 1,278 \\
\cline { 2 - 6 } & & 449 & 421 & 509 & 487 & 1,866
\end{tabular}

${ }^{\text {a }}$ Foreign operations defined with respect to the ForOps variable described in Table 2.

In Panel B of Table 1, we present a breakdown of our combined sample by government action, industry, and use of foreign operations. We note that the subsamples for each of our selected government actions contain comparable numbers of unique firms, ranging from 421 for the section 358(h) event period to 509 for the Circular 230 event period. On average, 47.3 percent of each subsample is comprised of manufacturing firms (SIC 3000-3999), followed by 20.3 percent from the hotels and services industry (SIC 7000-7999), 16.0 percent from wholesale and retail trade (SIC 5000-5999), 12.3 percent from construction (SIC 2000-2999), and 4.1 percent from services (SIC 8000-8999). Finally, we identify foreign operations (ForOps) by a U.S.-incorporated firm's reporting of non-zero amounts for foreign pretax income, foreign current income tax expense, and/or foreign deferred tax expense in Compustat. This classification yields approximately a 2:1 ratio of multinational to purely domestic firms for each government action, and multinational firms similarly outnumber purely domestic firms for all but the services and wholesale and retail trade industries. 


\subsection{Likelihood of Tax Sheltering}

For each of the subsamples described in Table 1, we estimate the Lisowsky (2010) and Wilson (2009) likelihood of tax sheltering (Shelter_L and Shelter $W$, respectively) on a quarterly basis, with minor adjustments. Specifically, both Lisowsky (2010) and Wilson (2009) include the continuous value of a firm's foreign income in their estimates. Lisowsky (2010) also includes a binary variable indicating whether a firm reported in Schedule 21 of its 10-K filing a subsidiary located in a tax haven jurisdiction. As suggested by RQ1, we seek to compare purely domestic firms (who face the full brunt of the U.S. corporate income tax system) to those with any foreign operations, and therefore are not concerned explicitly with the level of a firm's foreign income or its operations in deemed tax havens. Since the inclusion of either of these variables would only serve to bias the average estimated likelihood of tax sheltering upward for the subset of multinational firms we wish to compare with purely domestic firms, we exclude them from our estimates. Instead, we use our ForOps indicator to separately examine domestic and multinational firms in subsequent analyses. (Note 11)

Subject to the modifications described above, we obtain Shelter_L by applying regression coefficients from the "Combined Model (2)" in Table 4 of Lisowsky (2010) to the following quarterly profile of firm-level characteristics, with continuous values winsorized at the $1^{\text {st }}$ and $99^{\text {th }}$ percentiles: book-tax differences $(B T D)$, discretionary accruals $(D A P)$, Leverage, Size, ROA, research and development $(R \& D)$, lagged effective tax rate (LagETR), mezzanine financing (MezzFin), audit firm (BigN), litigation payments (Litigation), and net operating loss carryforwards (NOL). (Note 12) Similarly, we obtain Shelter_ $W$ by applying regression coefficients from the third model of Table 5 in Wilson (2009) to the winsorized variables $B T D, D A P$, Leverage, Size, ROA, and $R \& D$. We describe our variables in more detail in Table 2.

Table 2. Variable definitions

\begin{tabular}{ll} 
Variable & Definition \\
\hline BigN & $\begin{array}{l}1 \text { if a firm's auditor per Compustat is Deloitte, PricewaterhouseCoopers, Ernst \& Young, } \\
\text { KPMG, or Arthur Andersen, } 0 \text { otherwise. }\end{array}$ \\
\hline BTD & $\begin{array}{l}\text { Book-tax differences, or Compustat (pretax book income - estimated taxable income) / } \\
\text { total assets, where estimated taxable income }=\text { (current federal tax expense + current } \\
\text { foreign tax expense) / 0.35 - change in tax loss carryforward. }\end{array}$ \\
\hline DAP & $\begin{array}{l}\text { Performance-adjusted discretionary accruals. Consistent with Kothari et al. (2005) and } \\
\text { Amiram et al. (2013), DAP reflects an estimate of total discretionary accruals based on } \\
\text { the modified-Jones model (Dechow et al. 1995), adjusted by the median of all } \\
\text { discretionary accrual estimates for the same 2-digit SIC and quarter. }\end{array}$ \\
\hline ForOps & $\begin{array}{l}1 \text { for firms incorporated in the U.S. with foreign operations and 0 otherwise. Foreign } \\
\text { operations are evidenced by the reporting of non-zero amounts for at least one of the } \\
\text { following per Compustat: foreign pretax income, foreign income taxes, and/or foreign } \\
\text { deferred taxes. }\end{array}$ \\
\hline LagETR & Compustat (prior period tax expense / pretax book income) x 100. \\
\hline Leverage & Long-term debt / total assets per Compustat. \\
\hline Litigation & $\begin{array}{l}1 \text { if Compustat pretax or after-tax litigation/insurance settlement is negative (indicating a } \\
\text { payout), } 0 \text { otherwise. }\end{array}$ \\
\hline MezzFin & $\begin{array}{l}\text { Compustat convertible debt and preferred stock / total assets, or zero if convertible debt } \\
\text { and preferred stock is missing. }\end{array}$ \\
\hline NOL & 1 if Compustat tax loss carryforward is positive, 0 otherwise. \\
\hline R\&D & $\begin{array}{l}\text { Compustat research and development expense / lagged total assets, or 0 if research and } \\
\text { development expense is missing. }\end{array}$ \\
\hline ROA & Compustat pretax book income / total assets. \\
\hline Shelter_L & The Lisowsky (2010) estimated likelihood that a firm is engaged in a tax shelter. \\
\hline Shelter_W & The Wilson (2009) estimated likelihood that a firm is engaged in a tax shelter. \\
\hline The natural log of total assets per Compustat.
\end{tabular}




\subsection{Primary Analyses}

Our likelihood of tax sheltering estimates (Shelter_L and Shelter_ $W$ ) are combinations of multiple factors that have served as common controls in prior studies of corporate tax avoidance and have previously been shown to exhibit significant and simultaneous effects on a firm's tax aggressiveness and avoidance strategies (e.g., Wilson 2009; Lisowsky 2010; Amiram et al. 2013). Given that these factors are endogenous to our variables of interest and limit the inferences that may be drawn from a traditional regression approach, we construct firm-level averages for Shelter_L, Shelter_W, and their components for multiple event windows around each of our selected government actions and examine fluctuations in each measure using a series of paired t tests. As implied by H1, we expect Shelter_L and Shelter_ $W$ will on average decline for each government action. Similarly, we predict that the component measures with positive coefficients in the estimation of Shelter $L$ and Shelter $W$ described in Table 2 (BTD, DAP, Size, ROA, LagETR, BigN, Litigation, and NOL) will decline following each government action, while those with negative coefficients (Leverage and MezzFin) should increase, reflecting the change necessary to elicit an overall decline in the estimated likelihood of tax sheltering while holding all other factors constant. (Note 13) In other words, we expect to find decreases (increases) in variables found in prior research to be positively (negatively) related to tax sheltering, thereby decreasing (increasing) the influence of those variables on the estimated likelihood of tax sheltering in the periods following each government action. Our expected changes and results are reported in Table 3, using 2-, 4-, 6-, and 8-quarter event windows preceding and following each government action (excluding the effective quarter of each legislative change) in Panels A, B, C, and D, respectively.

Table 3. Aggregate response to selected government actions

Panel A: 2-Quarter Event Windows Preceding and Following Each Government Action

\section{Regulations}

Effective Quarter

No. Firms

Shelter_L
Shelter_W
BTD
DAP
Leverage
Size
ROA
R\&D
LagETR
MezzFin
BigN
Litigation
NOL

$$
2000 \text { Q1 }
$$$$
449
$$

Exp.

$\Delta \quad$ Pre Post $\Delta$

- $\quad 0.68$

0.70

0.

$-\quad 0.29$

0.35

$\begin{array}{llll}- & 0.010 .04 & 0.04\end{array}$

$+\quad 0.16$

$\begin{array}{lll}0.15 & -0.01\end{array}$

$\begin{array}{lll}0.00 & -0.01\end{array}$

$+\quad 0.03$

- 0.22

$+\quad 0.01$

- 0.88

- 0.98

\begin{tabular}{l}
$-\quad 0.29$ \\
\hline
\end{tabular}
$0.02 * * *$

$0.05 * * *$

Pre Post $\Delta$

$\begin{array}{llll}- & -0.02 & -0.03 & -0.01 *\end{array}$

$4.90 \quad 5.07 \quad 0.17 * * *$

2000 Q4
Section 358(h)

421
Circular 230

2005 Q2

509

\section{Regulations}

2007 Q3

487

\begin{tabular}{rrlrrlrrl} 
Pre & Post & $\boldsymbol{\Delta}$ & \multicolumn{1}{c}{ Pre } & Post & \multicolumn{1}{c}{$\boldsymbol{\Delta}$} & \multicolumn{1}{c}{ Pre } & \multicolumn{1}{c}{ Post } & $\boldsymbol{\Delta}$ \\
0.70 & 0.69 & $-0.01 *$ & 0.60 & 0.58 & $-0.02 * *$ & 0.59 & 0.61 & $0.02 * * *$ \\
0.35 & 0.32 & $-0.03 * * *$ & 0.38 & 0.29 & $-0.08 * * *$ & 0.31 & 0.36 & $0.05 * * *$ \\
-0.03 & -0.04 & $-0.02 * *$ & -0.07 & -0.07 & 0.00 & -0.06 & -0.06 & 0.00 \\
0.06 & -0.01 & $-0.06 * * *$ & 0.19 & -0.18 & $-0.37 * * *$ & -0.45 & -0.06 & $0.40 * * *$ \\
0.15 & 0.15 & 0.00 & 0.13 & 0.13 & -0.01 & 0.14 & 0.15 & 0.00 \\
5.08 & 5.11 & $0.04 * *$ & 4.91 & 4.99 & $0.08 * * *$ & 5.25 & 5.35 & $0.09 * * *$ \\
-0.01 & -0.03 & $-0.02 * * *$ & -0.06 & -0.05 & 0.00 & -0.05 & -0.05 & 0.00 \\
0.03 & 0.03 & 0.00 & 0.03 & 0.03 & 0.00 & 0.03 & 0.03 & 0.00 \\
0.21 & 0.18 & $-0.04 * * *$ & 0.15 & 0.17 & $0.02 *$ & 0.18 & 0.18 & 0.00 \\
0.01 & 0.01 & 0.00 & 0.01 & 0.01 & 0.00 & 0.01 & 0.01 & 0.00 \\
0.87 & 0.86 & -0.01 & 0.64 & 0.62 & $-0.02 * *$ & 0.60 & 0.60 & 0.00 \\
0.98 & 0.95 & $-0.03 * *$ & 0.92 & 0.92 & 0.00 & 0.91 & 0.92 & 0.01 \\
0.36 & 0.40 & $0.04 * *$ & 0.52 & 0.53 & 0.01 & 0.52 & 0.54 & $0.02 *$
\end{tabular}

Panel B: 4-Quarter Event Windows Preceding and Following Each Government Action

$\begin{array}{lcccc} & \text { 2000 Regulations } & \text { Section 358(h) } & \text { Circular 230 } & \text { 2007 Regulations } \\ \text { Effective Quarter } & 2000 \text { Q1 } & 2000 \text { Q4 } & 2005 \text { Q2 } & 2007 \text { Q3 } \\ \text { No. Firms } & 449 & 421 & 509 & 487\end{array}$

\begin{tabular}{|c|c|c|c|c|c|c|c|c|c|c|c|c|c|}
\hline & \multirow[b]{2}{*}{$\begin{array}{c}\text { Exp. } \\
\Delta\end{array}$} & & & & \\
\hline & & re & ost & $\Delta$ & re & os & $\Delta$ & re & os & $\mathbf{M}$ & $\mathrm{re}$ & ost & $\Delta$ \\
\hline helter_L & - & 0.68 & 0.70 & $0.01 * *$ & 0.69 & 0.69 & 0.00 & 0.60 & 0.59 & $-0.02 * *$ & 0.60 & 0.61 & $* *$ \\
\hline Shelter_W $W$ & - & 0.32 & 0.33 & 0.01 & 0.32 & 0.32 & 0.00 & 0.36 & 0.31 & -0. & 0.33 & 0.38 & $.05 * *$ \\
\hline$B T D$ & - & -0.02 & -0.04 & $-0.02 * *$ & -0.02 & -0.04 & $-0.02 * * *$ & -0.07 & -0.07 & -0.01 & -0.07 & -0.05 & 0.01 \\
\hline$D A P$ & - & 0.27 & 0.01 & $-0.26 * * *$ & 0.03 & 0.02 & -0.02 & 0.09 & -0.11 & $-0.20 *$ & -0.27 & 0.02 & $.29 *$ \\
\hline Leverage & + & 0.16 & 0.16 & 0.00 & 0.15 & 0.15 & 0.00 & 0.14 & 0.13 & -0.01 & 0.14 & 0.15 & 0.01 \\
\hline
\end{tabular}




$\begin{array}{lcrrrrrrrrrrrl}\text { Size } & - & 4.86 & 5.08 & 0.23 * * * & 5.01 & 5.10 & 0.09 * * * & 4.87 & 5.01 & 0.14 * * * & 5.22 & 5.35 & 0.13 * * * \\ \text { ROA } & - & 0.00 & -0.02 & -0.02 * * * & -0.01 & -0.04 & -0.03 * * * & -0.05 & -0.06 & -0.01 & -0.05 & -0.04 & 0.01 \\ \text { R\&D } & \pm & 0.03 & 0.03 & 0.00^{*} & 0.03 & 0.03 & 0.00^{* *} & 0.03 & 0.03 & 0.00 & 0.03 & 0.03 & 0.00 * * \\ \text { LagETR } & - & 0.22 & 0.20 & -0.02 * * & 0.21 & 0.17 & -0.04 * * * & 0.17 & 0.17 & 0.00 & 0.19 & 0.18 & 0.00 \\ \text { MezzFin } & + & 0.01 & 0.01 & 0.00 & 0.01 & 0.01 & 0.00 & 0.01 & 0.01 & 0.00 & 0.01 & 0.01 & 0.00 \\ \text { BigN } & - & 0.88 & 0.86 & -0.02 & 0.87 & 0.85 & -0.02 * * & 0.64 & 0.61 & -0.03 * * & 0.60 & 0.60 & 0.00 \\ \text { Litigation } & - & 0.98 & 0.96 & -0.03 * * & 0.98 & 0.95 & -0.04 * * & 0.92 & 0.89 & -0.03 * * & 0.91 & 0.91 & 0.00 \\ \text { NOL } & - & 0.29 & 0.37 & 0.08 * * * & 0.36 & 0.40 & 0.05 * * & 0.52 & 0.53 & 0.01 & 0.52 & 0.55 & 0.03 * *\end{array}$

Panel C: 6-Quarter Event Windows Preceding and Following Each Government Action

2000 Regulations

Effective Quarter

No. Firms

\author{
2000 Q1
}

449

Exp.
Section 358(h)

2000 Q4

421
Circular 230

2005 Q2

509

\section{Regulations}

2007 Q3

487

\begin{tabular}{|c|c|c|c|c|c|c|c|c|c|c|c|c|c|}
\hline & $\Delta$ & Pre & Post & $\Delta$ & Pre & Post & $\Delta$ & Pre & Post & $\Delta$ & Pre & Post & $\Delta$ \\
\hline elter $L$ & - & 68 & .69 & $0.01 * *$ & 0.69 & 0.68 & -0.01 & .60 & 0.59 & $-0.01 * *$ & 0.60 & 0.61 & 0.00 \\
\hline helte & - & 32 & 0.33 & $.02 * *$ & & 0.32 & $.01 * *$ & 36 & 0.32 & $-0.04 * * *$ & .34 & 0.36 & 02 \\
\hline$B T D$ & - & 2 & -0.04 & $0.02 * * *$ & 2 & 4 & -0.02 & 07 & 8 & -0.01 & -0.07 & -0.07 & 0.00 \\
\hline$D A P$ & - & 5 & 0.03 & $-0.21 * * *$ & 0.16 & 0.00 & $0.16 \cdots x$ & 0.03 & -0.10 & $-0.13 * * *$ & -0.19 & -0.05 & $*$ \\
\hline Lever & + & 6 & 0.16 & 0.00 & 0.15 & 0.14 & -0.01 & 0.14 & 0.13 & -0.01 & .14 & 0.15 & $1 \% *$ \\
\hline$z e$ & - & 4.85 & 5.0 & $4 * * *$ & 4.96 & 5.1 & $4 * * *$ & 4.84 & 5.03 & $19 * * *$ & 5.19 & 5.32 & $0.13 * x$ \\
\hline$O A$ & - & 0 & -0.03 & $-0.03 * * *$ & -0.01 & -0.04 & $-0.03 * * *$ & -0.05 & -0.06 & -0.0 & -0.05 & -0.06 & -0 . \\
\hline$\& D$ & \pm & 3 & 0.0 & $0 * *$ & 0.03 & 0. & 0. & 3 & 0 & 0 & 0.03 & 0.03 & $0 * *$ \\
\hline $\operatorname{gg} E$ & - & 0.22 & 0.19 & $-0.02 * *$ & 0.22 & 0. & $-0.05 * * *$ & 0.16 & 0.17 & 0.01 & 9 & 0.18 & -0 \\
\hline$e z$ & + & 0.01 & 0.01 & 0.00 & 0.0 & 0.01 & 0. & 0.01 & 0.01 & 0.00 & 01 & 1 & 0.00 \\
\hline$g I$ & - & 0.88 & 0.86 & -0 & 0.87 & 0.83 & -0 . & 4 & 0.60 & -0 . & 60 & 0.60 & 0.00 \\
\hline itiga & - & 0.98 & 0.94 & -0 & 0.98 & 0.94 & & 0.92 & 0.89 & 0 & & 1 & \\
\hline$U$ & & 2 & & & 6 & & t & .52 & .5 & & 0.52 & 0.55 & $0.03 *$ \\
\hline
\end{tabular}

Panel D: 8-Quarter Event Windows Preceding and Following Each Government Action

2000 Regulations

Effective Quarter

No. Firms 2000 Q1

449

Section 358(h)

2000 Q4

421
Circular 230

2005 Q2

509

\section{Regulations}

2007 Q3

487

Exp.

\begin{tabular}{|c|c|c|c|c|c|c|c|c|c|c|c|c|c|}
\hline & $\boldsymbol{\Delta}$ & re & Post & $\boldsymbol{\Delta}$ & Pre & ost & $\boldsymbol{\Delta}$ & Pre & Post & $\Delta$ & Pre & Post & $\Delta$ \\
\hline Shelter_L & - & 0.68 & 0.69 & 0.01 & 0.69 & 0.68 & -0.01 & 0.60 & 0.58 & $-0.02 * *$ & 0.60 & 0.60 & 0.00 \\
\hline Shelter_W $W$ & - & 0.31 & 0.32 & $0.01 *$ & 0.33 & 0.32 & -0.01 & 0.35 & 0.31 & $-0.03 * * *$ & 0.33 & 0.36 & $0.03 *$ \\
\hline$B T D$ & - & -0.02 & -0.04 & $-0.02 * * *$ & -0.02 & -0.04 & $-0.02 * * *$ & -0.07 & -0.08 & -0.01 & -0.06 & -0.07 & -0.01 \\
\hline$D A P$ & - & 0.24 & 0.00 & $-0.24 * * *$ & 0.14 & -0.03 & $-0.17 * * *$ & -0.02 & -0.17 & $-0.15 * * *$ & -0.19 & -0.06 & $0.13 * *$ \\
\hline verage & + & 0.16 & 0.15 & 0.00 & 0.15 & 0.14 & -0.01 & 0.14 & 0.13 & -0.01 & 0.14 & 0.15 & $0.02 * *$ \\
\hline$z e$ & - & 4.84 & 5.08 & $0.23 * * *$ & 4.93 & 5.09 & $0.16 * * *$ & 4.82 & 5.05 & $0.23 * * *$ & 5.16 & 5.30 & $0.14^{* *}$ \\
\hline$R O A$ & - & 0.00 & -0.03 & $-0.03 * * *$ & 0.00 & -0.04 & $-0.03 * * *$ & -0.06 & -0.06 & -0.01 & -0.05 & -0.06 & -0.01 \\
\hline$R \& D$ & \pm & 0.03 & 0.03 & $0.00 * *$ & 0.03 & 0.03 & $0.00 * *$ & 0.03 & 0.03 & 0.0 & 0.03 & 0.03 & $0.00 *$ \\
\hline $\operatorname{agETR}$ & - & 0.22 & 0.18 & $-0.03 * * *$ & 0.21 & 0.16 & $* * *$ & 0.16 & 0.17 & 0. & 0.19 & 0.17 & -0.02 \\
\hline$e z z F$ & + & 01 & 0.01 & 0. & .01 & 0.01 & $0.00 *$ & 0.01 & 0.01 & 0.0 & 0.01 & 0.01 & 0.00 \\
\hline $\operatorname{igN}$ & - & 0.88 & 0.83 & $-0.05 * *$ & 0.87 & 0.82 & $-0.06 * * *$ & 0.64 & 0.58 & $-0.05 *$ & 0.60 & 0.60 & 0.00 \\
\hline tigc & - & 0.98 & 0.93 & $-0.05 * * *$ & 0.98 & 0.93 & $-0.05 * *$ & 0.92 & 0.91 & -0.01 & 0.91 & 0.91 & 0.00 \\
\hline NOL & - & 0.29 & 0.39 & $0.10 * * *$ & 0.36 & 0.44 & $0.08 * * *$ & 0.52 & 0.53 & 0.01 & 0.52 & 0.55 & $0.03 * *$ \\
\hline
\end{tabular}

See Table 2 for variable definitions.

***, **, * Significant at the $<0.0001,0.05$, and 0.10 levels, respectively, using a paired $t$ test. 
For the 2000 Regulations, the first of our selected government actions to be implemented, Table 3 shows consistent increases in Shelter_L and Shelter_ $W$ for each event window, which does not support H1. Conversely, the firm-level changes in Shelter $\bar{L}$ and Shelter $-W$ shown in Table 3 provide evidence consistent with H1 for section 358(h) and Circular 230. For section 358(h), Shelter L L shows a significant decline of 1 percent in our two-quarter event window, while Shelter $W$ exhibits significant declines of 3 percent and 1 percent in our two- and six-quarter event windows, respectively. All other declines in Shelter_L and Shelter_ $W$ are directionally consistent with $\mathrm{H} 1$ but fail to achieve statistical significance. Under Circular 230, Shelter_ $L$ and Shelter_ $W$ significantly decline in all panels. These declines range from 1 (3) percent to 2 (8) percent for Shelter_L (Shelter_W).

While Table 3 shows consistent declines in Shelter_L and Shelter_W under section 358(h) and Circular 230, further examination of their components reveals the manner in which these changes manifested. Specifically, firms under section 358(h) exhibited significant declines in book-tax differences $(B T D)$, discretionary accruals $(D A P)$, litigation payments (Litigation), and ROA, which contributed to the net declines in Shelter_L and Shelter_W despite general increases in firm Size and NOL carryforwards (likely spurred by declining performance) that work against our findings. Interestingly, these same trends persist under the 2000 Regulations, which were enacted only three calendar quarters before section 358(h). This suggests that temporary increases in Shelter_L and Shelter_ $W$ under the 2000 Regulations likely reflect a brief period of adjustment to the government's initial attacks on corporate tax shelters that was largely resolved after the enactment of section 358(h). In addition, the government's new interest in corporate tax shelters reflected in the 2000 Regulations and section 358(h) appears to have encouraged a significant number of firms to seek new auditors outside of the BigN firms (five at that time, as Arthur Andersen's conviction from the Enron scandal did not occur until 2002) that were such heavy promoters of corporate tax shelters in the 1990 s, leading to a reduction in the average number of $B i g N$ audit clients in our sample that was sustained throughout the remaining government actions.

By comparison, the trend leading to significant declines in Shelter_L and Shelter_ $W$ under Circular 230 appears less complex. Table 3 shows that while Circular 230 spurred another modest proportion of firms to seek new auditors outside the BigN (now four firms, following the collapse of Arthur Andersen), the net reductions in Shelter_L and Shelter $W$ were mostly driven by a large-scale reversal of discretionary accruals $(D A P)$ in all panels. This suggests that Circular 230's unique focus on tax preparers, often the same firms whose audit practices were heavily scrutinized as the Sarbanes-Oxley Act of 2002 passed in the period between section 358(h) and Circular 230, may have contributed to an additional surge in professional skepticism and/or general accounting quality.

Unlike section 358(h) and Circular 230, Table 3 shows that the 2007 Regulations were ineffective in reducing Shelter_L and Shelter_W. The 2007 Regulations actually showed significant increases of 2 and 1 percent for Shelter $L$ in Panels A and B, which disappeared for the 6- and 8-quarter event periods shown in Panels C and D. Shelter_ $W$ increased for all four of our event windows, though similar to Shelter_L these increases were less severe for our extended windows in Panels $\mathrm{C}$ and D. Given that discretionary accruals $(D A P)$ and $N O L$ carryforwards increased significantly while $R O A$ slightly declined for our event windows that span much of 2008 and 2009, we attribute this temporary increase in the likelihood of tax sheltering to firms' efforts to salvage any available profits in response to the economic downturn that led to the Great Recession.

\subsection{Multinational vs. Purely Domestic Firms}

Before comparing average responses (i.e., changes) of multinational and purely domestic firms to each of our selected government actions as contemplated in RQ1, we first subdivide our original samples using our ForOps indicator and examine whether these groups exhibit significantly different baseline traits (i.e., levels) in each of our pre- and post-event periods. We present this comparison in Table 4 for our 4-quarter event period specification, reporting firm level averages before and after each government action in Panels A and B, respectively.

Table 4. Comparison of multinational and domestic firms before and after government actions

\section{Panel A: 4-Quarter Event Windows Preceding Each Government Action}

\section{Regulations}

Effective Quarter

Foreign Operations $^{\mathrm{a}}$ No Yes Total

No. Firms

\begin{tabular}{ccc}
\multicolumn{3}{c}{ Section 358(h) } \\
& 2000 & Q4 \\
No & Yes & Total \\
29 & 292 & 421
\end{tabular}

\begin{tabular}{ccc}
\multicolumn{3}{c}{ Circular 230} \\
& 2005 & Q2 \\
No & Yes & Total \\
159 & 350 & 509
\end{tabular}

\author{
2007 Regulations \\ 2007 Q3 \\ No Yes Total \\ $\begin{array}{lll}155 & 332 & 487\end{array}$
}




\begin{tabular}{|c|c|c|c|c|c|c|c|c|c|c|c|c|}
\hline & vg. & Avg. & Diff & Avg. & Avg. & Diff & Avg. & Avg. & Diff & Avg. & Avg. & Diff \\
\hline Shelter_L & 0.50 & 0.77 & $0.27^{\wedge \wedge \wedge}$ & 0.51 & 0.77 & $0.26^{\wedge \wedge \wedge}$ & 0.38 & 0.70 & $0.32^{\wedge \wedge \wedge}$ & 0.38 & 0.70 & $0.32^{\wedge}$ \\
\hline Shelter_W & 0.19 & 0.38 & $0.19^{\wedge \wedge \wedge}$ & 0.18 & 0.39 & $0.20^{\wedge \wedge \wedge}$ & 0.23 & 0.42 & $0.18^{\wedge \wedge \wedge}$ & 0.23 & 0.38 & $0.15^{\wedge}$ \\
\hline$B T D$ & -0.04 & -0.01 & $0.03^{\wedge \wedge}$ & -0.05 & -0.01 & $0.04^{\wedge}$ & -0.18 & -0.01 & $0.17^{\wedge \wedge \wedge}$ & -0.17 & -0.02 & $0.15^{\wedge \wedge}$ \\
\hline$D A P$ & 0.19 & 0.31 & $0.12^{\wedge}$ & 0.04 & 0.03 & -0.01 & -0.02 & 0.14 & $0.16^{\wedge \wedge}$ & -0.26 & -0.27 & -0.02 \\
\hline Leverage & 0.21 & 0.14 & $-0.07^{\wedge}$ & 0.19 & 0.13 & $-0.05^{\wedge \wedge}$ & 0.15 & 0.13 & -0.02 & 0.15 & 0.13 & -0.02 \\
\hline$z e$ & 3.84 & 5.34 & $1.51^{\wedge \wedge \wedge}$ & 3.97 & 5.47 & $1.50^{\wedge \wedge \wedge}$ & 3.51 & 5.49 & $1.98^{\wedge \wedge \wedge}$ & 3.90 & 5.84 & $1.94^{\wedge \wedge \wedge}$ \\
\hline$R O A$ & -0.03 & 0.01 & $0.04^{\wedge \wedge}$ & -0.04 & 0.01 & $0.05^{\wedge \wedge}$ & -0.17 & 0.00 & $0.17^{\wedge \wedge \wedge}$ & -0.15 & 0.00 & $0.15^{\wedge} \wedge$ \\
\hline$R \& D$ & 0.02 & 0.03 & 0.01 & 0.03 & 0.03 & 0.01 & 0.04 & 0.03 & $-0.02^{\wedge \wedge}$ & 0.05 & 0.02 & $-0.02^{\wedge \wedge}$ \\
\hline LagE1 & 0.19 & 0.23 & $0.04^{\wedge \wedge}$ & 0.18 & 0.22 & $0.04^{\wedge \wedge}$ & 0.17 & 0.16 & -0.01 & 0.17 & 0.20 & 0.03 \\
\hline MezzFin & 0.01 & 0.01 & 0.00 & 0.01 & 0.01 & 0.00 & 0.01 & 0.01 & 0.00 & 0.01 & 0.01 & 0.00 \\
\hline $\operatorname{BigN}$ & 0.77 & 0.92 & $0.15^{\wedge \wedge \wedge}$ & 0.74 & 0.93 & $0.18^{\wedge \wedge \wedge}$ & 0.41 & 0.74 & $0.33^{\wedge \wedge \wedge}$ & 0.39 & 0.70 & $0.31^{\wedge}$ \\
\hline tigat & 0.99 & 0.98 & -0.01 & 1.00 & 0.98 & $-0.02^{\wedge \wedge}$ & 0.91 & 0.93 & 0.02 & 0.91 & 0.91 & 0.00 \\
\hline $\mathrm{VOL}$ & 0.27 & 0.30 & 0.03 & 0.30 & 0.38 & $0.09^{\wedge}$ & 0.43 & 0.56 & $0.13^{\wedge \wedge}$ & 0.45 & 0.55 & $0.11^{\wedge}$ \\
\hline
\end{tabular}

Panel B: 4-Quarter Event Windows Following Each Government Action

\begin{tabular}{|c|c|c|c|c|c|c|c|c|c|c|c|c|}
\hline \multirow{3}{*}{$\begin{array}{l}\text { Effective Quarter } \\
\text { Foreign Operations }\end{array}$} & \multicolumn{3}{|c|}{2000 Regulations } & \multicolumn{3}{|c|}{ Section 358(h) } & \multicolumn{3}{|c|}{ Circular 230} & \multicolumn{3}{|c|}{2007 Regulations } \\
\hline & \multicolumn{3}{|c|}{2000 Q1 } & \multicolumn{3}{|c|}{2000 Q4 } & \multicolumn{3}{|c|}{2005 Q2 } & \multicolumn{3}{|c|}{2007 Q3 } \\
\hline & No & Yes & Total & No & Yes & Total & No & Yes & Total & No & Yes & Total \\
\hline No. Firms & 145 & 304 & 449 & 129 & 292 & 421 & 159 & 350 & 509 & 155 & 332 & 487 \\
\hline & Avg. & Avg. & Diff & Avg. & Avg. & Diff & Avg. & Avg. & Diff & Avg. & Avg. & Diff \\
\hline Shelter_L & 0.50 & 0.79 & $0.30^{\wedge \wedge \wedge}$ & 0.50 & 0.77 & $0.27^{\wedge \wedge \wedge}$ & 0.36 & 0.69 & $0.32^{\wedge \wedge \wedge}$ & 0.39 & 0.72 & $0.33^{\wedge \wedge \wedge}$ \\
\hline Shelter $W$ & 0.18 & 0.40 & $0.22^{\wedge \wedge \wedge}$ & 0.19 & 0.38 & $0.19^{\wedge \wedge \wedge}$ & 0.22 & 0.36 & $0.14^{\wedge \wedge \wedge}$ & 0.27 & 0.43 & $0.16^{\wedge \wedge \wedge}$ \\
\hline$B T D$ & -0.08 & -0.02 & $0.05^{\wedge \wedge}$ & -0.07 & -0.03 & $0.04^{\wedge}$ & -0.18 & -0.02 & $0.16^{\wedge \wedge \wedge}$ & -0.14 & -0.02 & $0.12^{\wedge \wedge \wedge}$ \\
\hline$D A P$ & -0.01 & 0.02 & 0.03 & -0.08 & 0.06 & $0.13^{\wedge \wedge}$ & -0.11 & -0.11 & 0.01 & 0.06 & 0.01 & -0.05 \\
\hline Leverage & 0.20 & 0.14 & $-0.06^{\wedge \wedge}$ & 0.18 & 0.13 & $-0.05^{\wedge}$ & 0.15 & 0.12 & -0.03 & 0.16 & 0.14 & -0.02 \\
\hline Size & 3.90 & 5.65 & $1.75^{\wedge} \wedge$ & 3.98 & 5.60 & $1.62^{\wedge \wedge \wedge}$ & 3.67 & 5.62 & $1.95^{\wedge \wedge \wedge}$ & 4.00 & 5.97 & $1.97^{\wedge \wedge}$ \\
\hline$R O A$ & -0.06 & 0.00 & $0.06^{\wedge}$ & -0.07 & -0.02 & $0.04^{\wedge}$ & -0.17 & -0.01 & $0.16^{\wedge \wedge \wedge}$ & -0.13 & 0.00 & $0.13^{\wedge \wedge \wedge}$ \\
\hline$R \& D$ & 0.02 & 0.03 & 0.01 & 0.03 & 0.03 & 0.00 & 0.05 & 0.03 & $-0.02^{\wedge \wedge}$ & 0.04 & 0.02 & $-0.02^{\wedge \wedge}$ \\
\hline LagETR & 0.17 & 0.21 & $0.05^{\wedge \wedge}$ & 0.14 & 0.18 & $0.04^{\wedge \wedge}$ & 0.16 & 0.17 & 0.02 & 0.17 & 0.19 & 0.02 \\
\hline MezzFin & 0.01 & 0.01 & 0.00 & 0.01 & 0.01 & $0.00^{\wedge}$ & 0.01 & 0.01 & 0.00 & 0.01 & 0.01 & 0.00 \\
\hline$B i g N$ & 0.72 & 0.92 & $0.20^{\wedge \wedge \wedge}$ & 0.71 & 0.91 & $0.20^{\wedge \wedge \wedge}$ & 0.38 & 0.71 & $0.32^{\wedge \wedge \wedge}$ & 0.38 & 0.70 & $0.32^{\wedge \wedge \wedge}$ \\
\hline Litigation & 0.98 & 0.95 & $-0.03^{\wedge}$ & 0.98 & 0.94 & $-0.04^{\wedge \wedge}$ & 0.86 & 0.90 & 0.04 & 0.94 & 0.89 & $-0.05^{\wedge}$ \\
\hline$N O L$ & 0.35 & 0.38 & 0.03 & 0.35 & 0.43 & 0.08 & 0.44 & 0.57 & $0.13^{\wedge \wedge}$ & 0.48 & 0.58 & $0.10^{\wedge \wedge}$ \\
\hline
\end{tabular}

See Table 2 for variable definitions.

$\wedge \wedge \wedge, \wedge, \wedge$ Significant at the $<0.0001,0.05$, and 0.10 levels, respectively, using the Satterthwaite method for two-sample t tests.

a Foreign operations defined with respect to the ForOps variable described in Table 2.

As shown in Table 4, our sample firms that lack foreign operations exhibit significantly lower estimated likelihoods of tax sheltering both before and after each of our selected government actions. Panel A shows that Shelter_L (Shelter_W) ranges from 70 to 77 percent (38 to 42 percent) for multinational firms and from 38 to 51 percent (18 to 23 percent) for purely domestic firms in the event periods preceding each of our government actions. Panel B shows similar disparity between multinational and purely domestic firms in our post-event periods, with Shelter_L (Shelter_ $W$ ) ranging from 69 to 79 percent (36 to 43 percent) and from 36 to 50 percent (18 to 27 percent) for firms with and without foreign operations, respectively. Focusing on the components of our likelihood measures, multinational firms on average have higher book-tax differences $(B T D)$, are larger (Size), perform better (ROA), and are more frequent clients of $B i g N$ audit firms both before and after each government action. Group differences in other measures only achieve significance for a portion of our selected government actions (e.g., Leverage, $R \& D$, and $N O L$ ), but we note that these differences generally persist both in quantity and statistical significance before and after each change in legislation. We further note that these results are qualitatively and quantitatively similar to 
untabulated analyses of our 2-, 6-, and 8-quarter event period specifications, and thus conclude that our ForOps indicator is effective in isolating disparate groups of multinational and purely domestic firms.

Having established that multinational and purely domestic firms differ with respect to the traits that comprise our estimated likelihoods of tax sheltering, we address RQ1 with a comparison of group-level changes for Shelter_L, Shelter_W, and their components in response to each of our selected government actions. We present the results of this analysis in Table 5, again using 2-, 4-, 6-, and 8-quarter pre- and post-event periods in Panels A through D.

Table 5. Comparison of multinational and domestic firm responses to government actions

Panel A: 2-Quarter Event Windows Preceding and Following Each Government Action

2000 Regulations

Eff. Qtr.

For. Ops. ${ }^{\mathrm{a}}$

No. Firms
Section 358(h) 2000 Q4
Circular 230

2005 Q2
2007 Regulations 2007 Q3

No Yes Total No Yes Total No Yes Total

$350 \quad 509$

155

332

487

Exp.

\begin{tabular}{|c|c|c|c|c|c|c|c|c|c|c|c|c|}
\hline & $\Delta$ & $\Delta$ & Diff & $\Delta$ & $\Delta$ & Diff & $\Delta$ & $\Delta$ & Diff & $\Delta$ & $\Delta$ & Diff \\
\hline Shelter_L & 0.01 & $0.03 * * *$ & $0.02^{\wedge \wedge}$ & $-0.02 *$ & -0.01 & 0.01 & -0.01 & $-0.02 * *$ & -0.01 & 0.00 & $0.02 * * *$ & ${ }^{k} 0.02^{\wedge \wedge}$ \\
\hline helter_W & $0.02 *$ & $07 * * *$ & $0.05^{\wedge \wedge}$ & -0.02 & $-0.04 * *$ & -0.02 & -0.02 & $-0.11 * * *$ & $*-0.09^{\wedge \wedge \wedge}$ & 0.01 & $0.07 * * *$ & $0.05^{\wedge \wedge}$ \\
\hline$B T D$ & - $\quad-0.01$ & $-0.01 * *$ & 0.00 & $-0.02 * *$ & $* *$ & 0.00 & 0.03 & $-0.01 *$ & -0.04 & 0.01 & 0.00 & -0.01 \\
\hline$D A P$ & $-\quad-0.03$ & $0.07 * * *$ & 0.10 & $-0.09 * *$ & $*-0.05 * * *$ & $* 0.04$ & $-0.18 * *$ & $*-0.46 * * *$ & $*-0.28^{\wedge \wedge}$ & $0.24 * * *$ & $0.47 * * *$ & ${ }^{k} 0.23^{\wedge \wedge}$ \\
\hline Leverage & +-0.02 & 0.00 & 0.02 & 0.01 & 0.00 & -0.01 & 0.01 & $-0.01 *$ & -0.02 & 0.00 & 0.01 & 0.01 \\
\hline Size & 0.03 & $0.24 * * *$ & $0.20^{\wedge \wedge \wedge}$ & ^-0.03 & $0.06^{* *}$ & $0.09^{\wedge}$ & $0.11 * *$ & $* 0.06^{* * *}$ & $*-0.05$ & $0.07 * *$ & $0.10 * * *$ & 0.03 \\
\hline$R O A$ & - $\quad-0.01$ & $-0.01 * *$ & 0.00 & $-0.02 * *$ & $*-0.02 * * *$ & $* 0.00$ & 0.03 & -0.01 & -0.04 & 0.01 & 0.00 & -0.01 \\
\hline$R \& D$ & $\pm \quad 0.00$ & 0.00 & 0.00 & 0.00 & $0.00 * *$ & $-0.01^{\wedge}$ & 0.00 & 0.00 & 0.00 & 0.00 & 0.00 & 0.00 \\
\hline LagETR & - $\quad-0.01$ & -0.01 & 0.00 & $-0.05 * *$ & $*-0.03 * *$ & 0.02 & -0.01 & $0.03 * *$ & $0.04^{\wedge \wedge}$ & 0.01 & -0.01 & -0.01 \\
\hline MezzFin & $+\quad 0.00$ & 0.00 & 0.00 & 0.00 & 0.00 & 0.00 & 0.00 & 0.00 & 0.00 & 0.00 & 0.00 & 0.00 \\
\hline$i g N$ & $-\quad-0.02$ & 0.01 & 0.03 & -0.02 & -0.01 & 0.00 & -0.01 & -0.02 & -0.01 & 0.00 & 0.00 & 0.00 \\
\hline itigation & 0.00 & 0.00 & 0.00 & -0.02 & $-0.04 * *$ & -0.03 & -0.01 & 0.00 & 0.01 & 0.03 & 0.00 & -0.03 \\
\hline VOL & 0.02 & $0.04 * *$ & 0.02 & $0.06^{* *}$ & $* 0.03 * *$ & -0.03 & 0.01 & 0.01 & 0.00 & 0.03 & 0.02 & -0.01 \\
\hline
\end{tabular}

Panel B: 4-Quarter Event Windows Preceding and Following Each Government Action

\begin{tabular}{|c|c|c|c|c|c|c|c|c|c|c|c|c|c|}
\hline \multirow{3}{*}{\multicolumn{2}{|c|}{$\begin{array}{l}\text { Eff. Qtr. } \\
\text { For. Ops. }^{\text {a }}\end{array}$}} & \multicolumn{3}{|c|}{2000 Regulations } & \multicolumn{3}{|c|}{ Section 358(h) } & \multicolumn{3}{|c|}{ Circular 230} & \multicolumn{3}{|c|}{2007 Regulations } \\
\hline & & \multicolumn{3}{|c|}{2000 Q1 } & \multicolumn{3}{|c|}{2000 Q4 } & \multicolumn{3}{|c|}{2005 Q2 } & \multicolumn{3}{|c|}{2007 Q3 } \\
\hline & & No & Yes & Total & No & Yes & Total & No & Yes & Total & No & Yes & Total \\
\hline o. Firms & & 145 & 304 & & 129 & 292 & & 159 & 350 & 509 & 155 & 332 & 487 \\
\hline \multicolumn{14}{|c|}{ Exp. } \\
\hline & $\Delta$ & $\Delta$ & $\Delta$ & Diff & $\Delta$ & $\Delta$ & Diff & $\Delta$ & $\Delta$ & Diff & $\Delta$ & $\Delta$ & Diff \\
\hline helter_L & - & 0.00 & $0.02 * *$ & $0.03^{\wedge \wedge}$ & -0.01 & 0.00 & .01 & $-0.01 * *$ & $*-0.02 * *$ & 0.00 & 0.00 & $0.02 * *$ & $0.02^{\prime}$ \\
\hline helter_W & - & -0.01 & $0.02 * *$ & $0.03^{\wedge \wedge}$ & 0.00 & 0.00 & -0.01 & -0.01 & -0.0 & $*-0.04^{\wedge \wedge}$ & $0.04 * *$ & $0.06^{* * *}$ & * 0.02 \\
\hline$B T D$ & - & $-0.03 * *$ & $-0.01 * *$ & 0.02 & $-0.02 * *$ & k $-0.02 * * *$ & 0.00 & 0.01 & $-0.01 * *$ & -0.02 & 0.03 & 0.00 & -0.02 \\
\hline$D A P$ & - & $-0.20 * *$ & $-0.28 * * *$ & *-0.08 & $-0.12 * *$ & $0.03 *$ & $0.15^{\wedge \wedge}$ & 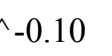 & $-0.25 * * *$ & $*_{-}-0.15^{\wedge \wedge}$ & $0.31 * * *$ & $0.28 * * *$ & $*-0.03$ \\
\hline Leverage & + & -0.01 & 0.00 & 0.01 & 0.00 & 0.00 & 0.00 & 0.00 & $-0.02 * *$ & -0.02 & 0.01 & $0.01 *$ & 0.00 \\
\hline Size & - & 0.07 & $0.31 * * *$ & $0.24^{\wedge \wedge \wedge}$ & 0.01 & $0.13 * * *$ & ${ }^{k} 0.12^{\wedge \wedge}$ & $0.16^{*}$ & $* 0.13^{* * *}$ & $*_{-}-0.04$ & $0.10^{* *}$ & $0.14 * * *$ & * 0.03 \\
\hline
\end{tabular}




$\begin{array}{lccccccccccccc}\text { ROA } & - & -0.04^{* *}-0.02^{* *} & 0.02 & -0.03^{* *}-0.03^{* * *} & 0.00 & 0.01 & -0.01^{* *} & -0.02 & 0.02 & 0.00 & -0.02 \\ \text { R\&D } & \pm & 0.00 & 0.00^{*} & 0.00 & 0.00 & 0.00^{* * *}-0.01^{\wedge} & 0.00 & 0.00 & 0.00 & -0.01 * & 0.00^{*} & 0.01 \\ \text { LagETR } & - & -0.02^{*} & -0.02^{*} & 0.00 & -0.04^{* *}-0.04^{* * *} & 0.00 & -0.01 & 0.01 & 0.03^{\wedge} & 0.00 & 0.00 & 0.00 \\ \text { MezzFin } & + & 0.00 & 0.00 & 0.00 & 0.00 & 0.00^{*} & 0.00^{\wedge} & 0.00 & 0.00 & 0.00 & 0.00 & 0.00 & 0.00 \\ \text { BigN } & - & -0.05^{* *} & 0.00 & 0.05^{\wedge} & -0.03 & -0.01 & 0.02 & -0.03 & -0.03 * * & -0.01 & -0.01 & 0.00 & 0.01 \\ \text { Litigation } & - & -0.01 & -0.03^{* *} & -0.02 & -0.02^{*} & -0.04^{* *} & -0.02 & -0.05 & -0.03 & 0.03 & 0.03 & -0.02 & -0.05 \\ \text { NOL } & - & 0.08^{* *} & 0.08^{* *} & 0.00 & 0.05^{* *} & 0.05^{* *} & -0.01 & 0.01 & 0.01 & 0.00 & 0.03 & 0.02 & -0.01\end{array}$

Panel C: 6-Quarter Event Windows Preceding and Following Each Government Action

\section{Regulations}

Eff. Qtr.

For. Ops. $^{\text {a }}$ No $\quad$ Yes Total No Yes Total No

$\begin{array}{lllllll}\text { No. Firms } & 145 & 304 & 449 & 129 & 292 & 421\end{array}$
Circular 230

2005 Q2

Yes Total No Yes Total Exp. $\begin{array}{lllll}350 & 509 & 155 & 332 & 487\end{array}$

$\begin{array}{lllllllllllll}\Delta & \Delta & \Delta & \text { Diff } & \Delta & \Delta & \text { Diff } & \Delta & \Delta & \text { Diff } & \Delta & \Delta & \text { Diff }\end{array}$

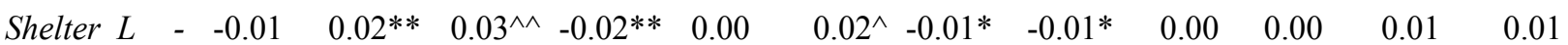

Shelter $W-0.00 \quad 0.03 * * * 0.03^{\wedge \wedge} \quad 0.00 \quad-0.02 * *-0.01 \quad-0.01 \quad-0.05^{* * *}-0.03^{\wedge \wedge} 0.03 * * \quad 0.02 * * \quad-0.01$

$B T D-\quad-\quad-0.03 * *-0.02 * * * 0.02 \quad-0.03 * *-0.02 * * * 0.01 \quad-0.01 \quad-0.01 * * \begin{array}{lllllll}0 & 0.00 & 0.01 & -0.01 * & -0.02\end{array}$

$D A P \quad-\quad-0.21 * *-0.22 * * *-0.01 \quad-0.17 * *-0.16^{* * *} 0.01 \quad-0.09 \quad-0.15 * * *_{-} 0.06 \quad 0.18 * * \quad 0.13 * * *-0.06$

Leverage $+\begin{array}{llllllllllll}-0.01 & 0.00 & 0.01 & -0.01 & 0.00 & 0.01 & 0.01 & -0.02 * * & -0.03^{\wedge} & 0.02 & 0.01 * * & 0.00\end{array}$

Size $\quad-0.07 \quad 0.32 * * * 0.25^{\wedge \wedge \wedge} 0.02 \quad 0.19 * * * 0.18^{\wedge \wedge} 0.20 * * * 0.18^{* * *}-0.03 \quad 0.11 * * 0.14 * * * 0.03$

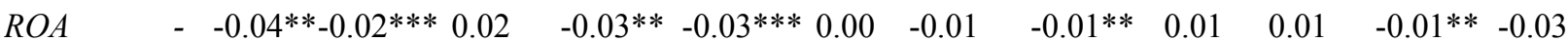

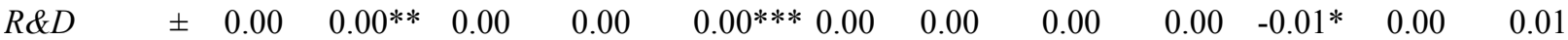

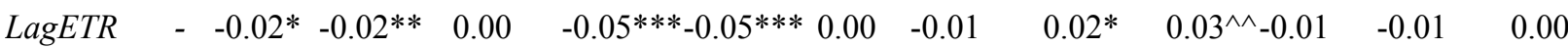

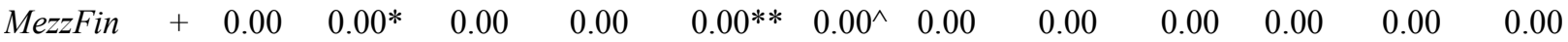

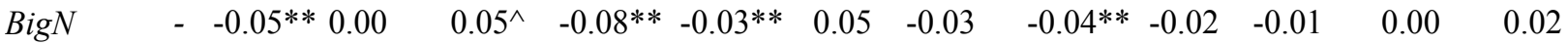

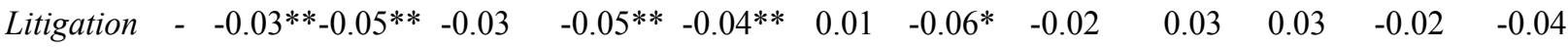

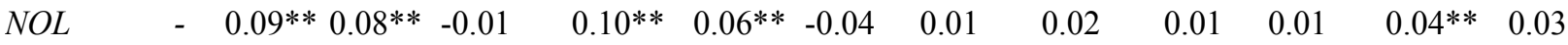

Panel D: 8-Quarter Event Windows Preceding and Following Each Government Action

\section{Regulations}

Eff. Qtr. 2000 Q1

For. Ops. ${ }^{\text {a }} \quad$ No $\quad$ Yes Total No Yes Total No

No. Firms $\quad 145 \quad 304 \quad 449 \quad 129$

Section 358(h)
$\begin{array}{ccc}2000 & & \\ \text { Yes } & \text { Total } & \text { No } \\ 292 & 421 & 159\end{array}$

Circular 230

2005 Q2

Yes Total No Yes Total

$$
\text { Exp. }
$$

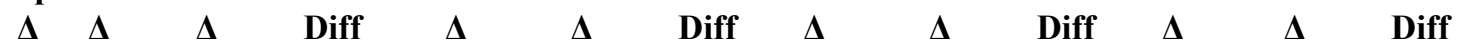

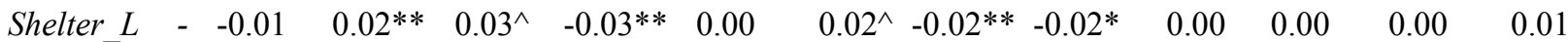

Shelter $W-\quad-0.01 \quad 0.02^{* *} \quad 0.02^{\wedge \wedge} \quad 0.01 \quad-0.02^{* *}-0.02^{\wedge \wedge}-0.01 \quad-0.04^{* * *}-0.03^{\wedge \wedge} 0.04^{* *} \quad 0.02^{* *}-0.02$

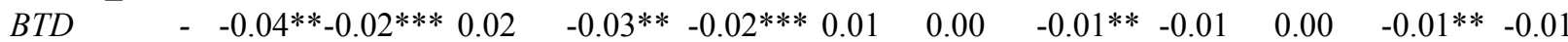

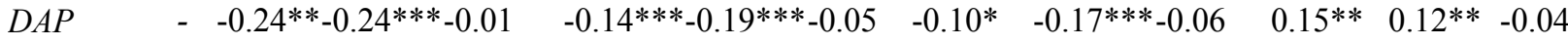

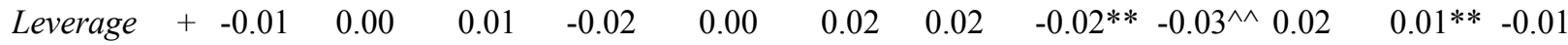

Size $\quad-\quad 0.06 \quad 0.32 * * * 0.26^{\wedge \wedge \wedge} 0.02 \quad 0.22^{* * *} 0.20^{\wedge \wedge} 0.25 * * * 0.22 * * *-0.03 \quad 0.11^{* *} \quad 0.15^{* * *} 0.04$

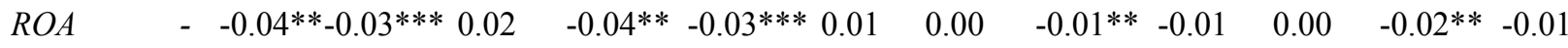

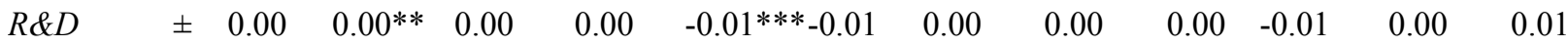

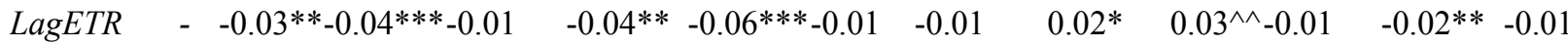

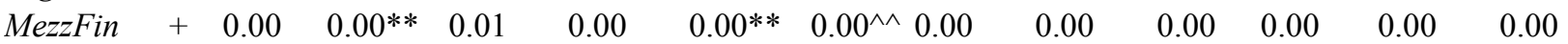




$\begin{array}{llllllllllllrr}\text { BigN } & - & -0.09^{* *}-0.02 & 0.07^{\wedge \wedge} & -0.09^{* *} & -0.04^{* *} & 0.05^{\wedge} & -0.04^{* *} & -0.06^{* *} & -0.02 & -0.01 & 0.01 & 0.01 \\ \text { Litigation } & - & -0.05^{* *}-0.05^{* *} & 0.00 & -0.07^{* *} & -0.05^{* *} & 0.03 & -0.01 & -0.01 & -0.01 & 0.02 & -0.01 & -0.03 \\ \text { NOL } & - & 0.09^{* *} & 0.10^{* * *} & 0.01 & 0.09^{* *} & 0.08^{* *} & -0.02 & 0.01 & 0.01 & 0.01 & 0.01 & 0.04 * * & 0.03\end{array}$

See Table 2 for variable definitions.

$* * *, * *, *$ Significant at the $<0.0001,0.05$, and 0.10 levels, respectively, using a paired $t$ test.

$\wedge \wedge \wedge, \wedge$, ^ Significant at the $<0.0001,0.05$, and 0.10 levels, respectively, using the Satterthwaite method for

two-sample $\mathrm{t}$ tests.

${ }^{\text {a }}$ Foreign operations defined with respect to the ForOps variable described in Table 2.

For the 2000 Regulations, we show in each panel of Table 5 that the aggregate increases in Shelter_L and Shelter_W previously observed in Table 3 are driven by multinational firms. Conversely, purely domestic firms are largely responsible for aggregate declines in the number of $B i g N$ audit clients previously observed in Table 3. Perhaps speaking to the insulating effects of foreign operations from increased government interest in tax shelters, multinational firms exhibit significantly higher growth (Size) in the event periods following the 2000 Regulations.

However, we observe largely similar declines in Shelter_ $L$ and Shelter_ $W$ for both groups of firms under section $358(\mathrm{~h})$, which was enacted only three quarters after the 2000 Regulations. This suggests that multinational firms were merely slower to respond to the government's initial attacks on corporate tax shelters, which seems reasonable given that multinational firms were shown in Table 4 to be larger and more complex organizations and by definition have a larger geographical footprint than their purely domestic counterparts.

Under Circular 230, we find that multinational firms were slightly quicker to respond in our 2-quarter event window, exhibiting a significantly larger decline for Shelter_ $W$ in Panel A that persists in Panels B though D. Multinational firms maintain a slight but statistically insignificant edge for the decline in Shelter_L over all but the eight-quarter event window. However, this may be largely attributable to differences in sample size, as our results for the components of Shelter_L and Shelter_ $W$ reveal no meaningful differences in differences other than a decline in discretionary accruals $(D A P)$ that favors multinational firms in Panels A and B. Thus, Table 5 suggests overall that the government actions deemed most effective in our previous analyses (i.e., section 358(h) and Circular 230) elicited qualitatively similar responses from multinational and purely domestic firms, although purely domestic firms proved slightly nimbler when the government's first attacks on corporate tax shelters were launched.

For the 2007 Regulations, we find that the aggregate increases in Shelter_L and Shelter_ $W$ previously reported in Table 3 are largely driven by multinational firms. We find that multinational firms increased discretionary accruals on a significantly larger scale in our 2-quarter event period, which contributed to a significantly larger increase in Shelter_W (Shelter_L) in Panel A (Panels A and B). Both sets of firms exhibit statistically significant, but roughly equivalent, increases in Shelter_W in Panels B through D.

\subsection{Sensitivity Tests}

As reflected in Table 1, the samples for each of our selected government actions span multiple industries, but nearly half of our unique firms engage in some form of manufacturing (SIC 3000-3999). To gauge whether our primary results are sensitive to this sample composition, we performed all of the same analyses shown in Tables 3 through 5 on separate industries by 1-digit SIC. While not reported, our industry-specific results remain qualitatively consistent with our original analyses, and we conclude that our findings are not isolated to a particular industry.

In addition, our discussion in Section 2 indicates that both section 358(h) and the 2007 Regulations were proposed several quarters before they became effective and Circular 230 had been previously revised less than six months before our chosen effective date. Thus, our tabulated results may be artifacts of market-wide reactions to government attacks on corporate tax shelters that began prior to the effective dates we chose to define our event periods. In untabulated analyses, we reexamine section 358(h) using the fourth quarter of 1999 to define our event periods, as this quarter includes the date on which a similar act was proposed by Senator Roth (see note 3). Similarly, we reexamine Circular 230 around its earlier revision in the fourth quarter of 2004. Finally, we reexamine the 2007 Regulations around the fourth quarter of 2006 when they were first proposed (see note 9). Overall, the results of these supplemental tests are consistent with those reported in Table 5, and our inferences remain unchanged. (Note 14) 


\section{Conclusion}

The 1990s marked a period of rapid expansion and proliferation of corporate tax shelters by public accounting firms, eventually achieving critical mass and prompting regulatory action from Congress, the U.S. Treasury, and the IRS (Novak and Saunders 1998; Treasury 1999). Since 2000, several government actions have been implemented in efforts to deter this aggressive form of corporate tax avoidance, often with much fanfare and great expectations for revenue collections. However, despite the government's multiple and varied attempts in recent years to combat corporate tax shelters, to date there is little evidence indicating whether these attempts have or have not been effective.

Given that privacy restrictions on tax return data generally prevent positive identification of tax sheltering activities, we investigate whether various attempts by Congress, the U.S. Treasury, and the IRS to curb the proliferation of tax shelters and/or close loopholes in the Internal Revenue Code (IRC) have had a discernable effect on firms' estimated likelihood of tax sheltering (Wilson 2009; Lisowsky 2010). These measures reflect a wide assortment of publicly disclosed information that has been linked to the aggressive practices of known tax shelter users. We specifically examine the effectiveness of four recent government actions at eliciting measurable decreases in a firm's estimated likelihood of tax sheltering using a pre-post design with event windows of varying lengths. Of these four government actions, the first three - the 2000 Regulations, section 358(h), and Circular 230 - produced consistent evidence of a decline in characteristics associated with the use of tax shelters.

For the 2000 Regulations and section 358(h), which were enacted in the same year, examination of the components of the estimated likelihood of tax sheltering suggest that the average firm response to these initial attacks on corporate tax shelters was complex and multi-faceted. Sample firms for each of these government actions exhibited significant declines in book-tax differences, discretionary accruals, litigation payments, and performance while also migrating away from the Big N audit firms who championed a number of tax shelters in the 1990s. Still, our results show temporary increases in the overall estimated likelihood of tax sheltering immediately after the 2000 Regulations, revealing a period of adjustment that had largely reversed by the time section 358(h) was implemented some three quarters later. On the other hand, the aggregate decline in the estimated likelihood of tax sheltering under Circular 230, a preparer-focused piece of legislation, was immediate and largely driven by reductions in discretionary accruals, perhaps suggesting an increase in professional skepticism and/or accounting quality amid increasing government scrutiny. Separate analysis for multinational and purely domestic firms indicates that all three of these government actions elicited qualitatively similar responses from firms with and without foreign outlets for tax avoidance.

Unlike our first three selected government actions, the 2007 Regulations proved relatively ineffective in our analyses. These regulations were enacted shortly before the economic downturn that led to the Great Recession, and significant increases in discretionary accruals and NOL carryforwards in conjunction with declining performance in the period following the change in legislation suggest that temporary increases in the estimated likelihood of tax sheltering were likely the result of firms' efforts to combat heightened economic pressures. Additional analysis suggests that multinational firms were largely responsible for increases in the estimated likelihood of tax sheltering following the 2007 Regulations, while purely domestic firms' reactions were relatively less severe.

Our contributions to the tax literature are at least twofold. First, pursuant to the calls by Shackelford and Shevlin (2001) and Hanlon and Heitzman (2010) for a better understanding of factors determining corporate tax avoidance, we offer new evidence on the government's efforts to discourage a highly aggressive form of corporate tax avoidance that managers might otherwise pursue in order to please investors and maximize firm value (Slemrod 2004; Crocker and Slemrod 2005; Desai et al. 2007; Hoopes et al. 2012). Second, we offer evidence of multi-faceted taxpayer reactions to corporate tax reform. Such variety and complexity in corporate responses to tax reform suggests that various pieces of legislation can produce similarly encouraging results for vastly different reasons (e.g., section 358(h) vs. Circular 230), or perhaps yield disappointing results due to issues largely beyond regulatory control (e.g., the 2007 Regulations). Thus, the questions raised in this study should likely be revisited with subsequent revisions to the tax system in order to gain a better understanding of what does and doesn't work as the federal government presumably learns from past experience and tries to devise new ways of discouraging tax shelter activities.

\section{Acknowledgements}

We gratefully acknowledge Andrew Blair-Stanek, Steve Buchheit, Heather Carrasco, Marcus Doxey, Adam Nowak, Tom Omer, Troy Pollard, Mary Stone, and workshop participants at the University of Alabama for their helpful comments and suggestions. All errors are our own. 


\section{References}

Amiram, D., Bauer, A. M., \& Frank, M. M. (2013). Corporate Tax Avoidance and Managerial Incentives Generated by Shareholder Dividend Tax Policy. Darden Business School Working Paper No. 2111467. http://dx.doi.org/10.2139/ssrn.2111467

Auerbach, A. J., \& Hassett, K. A. (2007). The 2003 Dividend Tax Cuts and the Value of the Firm: An Event Study. In A. Auerbach, J. Hines, \& J. Slemrod (Eds.), Taxing Corporate Income in the 21st Century. Cambridge University Press.

Crocker, K. J., \& Slemrod, J. (2005). Corporate tax evasion with agency costs. Journal of Public Economics, 89(910), 1593-1610. http://dx.doi.org/10.1016/j.jpubeco.2004.08.003

Dechow, P. M., Sloan, R. G., \& Sweeney, A. P. (1995). Detecting Earnings Management. The Accounting Review, 70(2), 193-225. http://dx.doi.org/10.2307/248303

Desai, M. A., Dyck, A., \& Zingales, L. (2007). Theft and taxes. Journal of Financial Economics, 84(3), 591-623. http://dx.doi.org/10.1016/j.jfineco.2006.05.005

Dhaliwal, D., Krull, L., \& Li, O. Z. (2007). Did the 2003 Tax Act reduce the cost of equity capital? Journal of Accounting and Economics, 43, 121-150. http://dx.doi.org/10.1016/j.jacceco.2006.07.001

Donohoe, M. P., McGill, G. A., \& Outslay, E. (2014). Risky Business: The Prosopography of Corporate Tax Planning. National Tax Journal, 67(4), 851-874.

Feldstein, M. (1995). The Effect of Marginal Tax Rates on Taxable Income: A Panel Study of the 1986 Tax Reform Act. Journal of Political Economy, 103(3), 551-572. http://dx.doi.org/10.2307/2138698

Givoly, D., Hayn, C., Aharon, R. O., \& Sarig, O. (1992). Taxes and Capital Structure: Evidence from Firms' Response to the Tax Reform Act of 1986. The Review of Financial Studies, 5(2), 331-355. http://dx.doi.org/10.2307/2962034

Hanlon, M., \& Heitzman, S. (2010). A review of tax research. Journal of Accounting and Economics, 50(2-3), 127-178. http://dx.doi.org/10.1016/j.jacceco.2010.09.002

Harvey, J. R. (2014). Corporate Tax Aggressiveness - Recent History and Policy Options. National Tax Journal, 67(4), 831-850.

Hoopes, J. L., Mescall, D., \& Pittman, J. A. (2012). Do IRS Audits Deter Corporate Tax Avoidance? Accounting Review, 87(5), 1603-1639. http://dx.doi.org/10.2308/accr-50187

Kothari, S. P., Leone, A. J., \& Wasley, C. E. (2005). Performance matched discretionary accrual measures. Journal of Accounting and Economics, 39(1), 163-197. http://dx.doi.org/10.1016/j.jacceco.2004.11.002

Lisowsky, P. (2010). Seeking Shelter: Empirically Modeling Tax Shelters Using Financial Statement Information. Accounting Review, 85(5), 1693-1720. http://dx.doi.org/10.2308/accr.2010.85.5.1693

Novak, J., \& Saunders, L. (1998). THE HUSTLING OF X RATED SHELTERS. (cover story). Forbes, 162(13), 198-208.

Shackelford, D. A., \& Shevlin, T. (2001). Empirical tax research in accounting. Journal of Accounting and Economics, 31(1-3), 321-387. http://dx.doi.org/10.1016/S0165-4101(01)00022-2

Slemrod, J. (2004). The Economics of Corporate Tax Selfishness. National Tax Journal, 57(4), 877-899.

Treasury, U. S. (1999). The Problem of Corporate Tax Shelters: Discussion, Analysis and Legislative Proposals. Washington, D.C.: Government Printing Office.

Wilson, R. J. (2009). An Examination of Corporate Tax Shelter Participants. The Accounting Review, 84(3), 969-999. http://dx.doi.org/10.2308/accr.2009.84.3.969

\section{Notes}

Note 1 . Since 2000, the federal government has implemented four changes in individual income tax rates while leaving the top corporate income tax rate unchanged at 35 percent.

Note 2. Unless otherwise indicated, all references herein to "Code" or "section" are to the Internal Revenue Code of 1986 , as amended, and all references to "Regulation" are to the U.S. Treasury regulations promulgated thereunder. 
Note 3. Senator Roth, then Chairman of the Senate Committee on Finance, previously released a substantially similar provision for markup on October 19, 1999.

Note 4. According to Circular $230 \S 10.2(\mathrm{a})(4)$, practice before the IRS includes, but is not limited to, preparing documents, filing documents, corresponding and communicating with the IRS, rendering written advice with respect to any entity, transaction, plan or arrangement, and representing a client at conferences, hearings and meetings.

Note 5. Circular $230 \S 10.2(a)(8)$ defines "tax return preparer" to mean "any individual within the meaning of section 7701(a)(36) and 26 CFR 301.7701-15."

Note 6. Given the close proximity of these two changes to Circular 230, we base our primary analyses around the latter revision in May 2005. Since our pre-event period includes the enactment of the first Circular 230 revision, which likely elicited concern and early reactions among tax preparers, this design choice serves to bias against findings of statistical significance. We note, however, that our inferences are not sensitive to this chosen event period.

Note 7. Generally, a covered opinion is any written advice (including electronic communications) that either (1) involves a transaction the IRS has determined is a tax-avoidance transaction, (2) has a principal purpose of tax avoidance, or (3) has tax avoidance as a significant purpose and is either (i) a reliance opinion, (ii) a marketed opinion, (iii) is subject to conditions of confidentiality, or (iv) is subject to contractual protection.

Note 8. Written advice generally constitutes a "marketed opinion" under the revised Circular 230 regulations if the tax practitioner knows or has reason to know the written advice will be used or referred to by a person other than the tax practitioner (or anyone in the tax practitioner's firm) in promoting, marketing, or recommending a partnership or other entity, investment plan or arrangement to one or more taxpayers. Written advice is generally subject to conditions of confidentiality if the tax practitioner imposes one or more limitations on disclosure of the tax treatment or tax structure of the transaction on one or more recipients of the written advice, regardless of whether the limitation is legally binding. Written advice is subject to contractual protection if the recipient has the right to a full or partial refund of the tax practitioner's fees if all or part of the intended tax consequences from the matters addressed in the written advice are not sustained or if the fees paid to the tax practitioner are contingent on the recipient's realization of tax benefits from the transaction.

Note 9. The IRS and U.S. Treasury had previously issued proposed Regulations on November 1, 2006.

Note 10. The effective quarters described in Section 2 for each of our selected government actions are as follows. The 2000 Regulations and section 358(h) were put into effect in Q1 and Q4 of 2000, respectively. Our featured amendment to Circular 230 was implemented in Q2 of 2005. Finally, the 2007 Regulations were put into effect in Q3 of 2007. We examine alternative event dates for some of our government actions in sensitivity analyses.

Note 11. In untabulated tests, we include foreign income and use our ForOps indicator in place of the Lisowsky (2010) tax haven indicator to estimate our tax sheltering likelihood measures. Our inferences remain unchanged.

Note 12. We use Lisowsky's "Combined Model (2)" in our reported estimates because the model included year and industry controls, thereby eliminating some degree of variation attributable to characteristics of his sample selection that differ from ours. In untabulated analyses, we obtain qualitatively similar results using the regression coefficients reported for Lisowsky's "Combined Model (1)," which excluded year and industry controls.

Note 13. The coefficients obtained by Wilson (2009) and Lisowsky (2010) for research and development are of opposite signs. Therefore, we make no directional prediction for $R \& D$.

Note 14. We do not examine alternative dates for the 2000 Regulations because temporary and proposed regulations were issued at the same time, suggesting that there was no observable forewarning of this legislative act. 